\title{
Environmental Sustainability in Beef Production and Life Cycle Assessment as a Tool for Analysis
}

\author{
Pedro Henrique Presumido ${ }^{1}$, Fernando Sousa ${ }^{2}$, Artur \\ Gonçalves $^{3}$, Tatiane Cristina Dal Bosco ${ }^{4}$, Manuel Feliciano ${ }^{5}$ \\ ${ }^{1}$ Doctoral Program in Environmental Engineering, Faculty of Engineering, University of \\ Porto, Porto, Portugal (pedro.presumido@fe.up.pt) ORCID 0000-0001-8134-9594; \\ ${ }^{2}$ Mountain Research Center (CIMO), Institute Polytechnic of Bragança, Campus Santa \\ Apolónia, Bragança, Portugal (fsousa@ipb.pt) ORCID 0000-0002-8895-3839; \\ ${ }^{3}$ Mountain Research Center (CIMO), Institute Polytechnic of Bragança, Campus Santa \\ Apolónia, Bragança, Portugal (ajg@ipb.pt) ORCID 0000-0002-4825-6692; ${ }^{4}$ Department \\ of Environmental Engineering, Federal University of Technology - Paraná, Estr. dos \\ Pioneiros, 3131 - Jardim Morumbi, Londrina - PR, Brazil (tatianebosco@utfpr.edu.br) \\ ORCID 0000-0002-2470-9853; ${ }^{5}$ Mountain Research Center (CIMO), Institute \\ Polytechnic of Bragança, Campus Santa Apolónia, Bragança, Portugal \\ (msabenca@ipb.pt) ORCID 0000-0002-3147-4511
}

\begin{abstract}
The sustainability of meat production systems has been highlighted by the impact on the environment and the conservation of natural resources. The aim of this manuscript is to provide a specific review of the environmental sustainability of beef production in a life cycle assessment (LCA) context. Questions about the main environmental impacts caused by beef production were discussed. The phases of the LCA were detailed as well as the main functional units, boundaries of the systems and categories of impacts used in recent studies. LCA is a fast, easy and intuitive method that correlates human activities and their environmental performance in different sectors, such as beef production.
\end{abstract}

Author Keywords. Life Cycle Assessment, Circular Economy, Environmental Management, Environmental Assessment, Beef Production.

Type: Review Article

วิ Open Access $\square$ Peer Reviewed $\oplus$ CC BY

\section{Introduction}

Food production requires large amounts of material and energy resources and is responsible for the emission of various wastes, which cause a number of negative effects on the environment. In the present day society, environmental impacts come from two main issues: the decrease in the supply of fossil fuels and the limited availability of renewable resources; and the production of wastes with subsequent disposal into the environment without proper treatment. Both can be considered as an effect of the technological development of human society (Brown and Ulgiati 2002).

Meat production is one of the most important economic sub-sectors of the agri-food sector. The largest producers of this industry are the United States, Brazil, European Union (EU) and China, respectively, representing almost the total annual production of 60 million tons of carcass weight per year (USDA 2016).

EU has a cattle population of about 87 million head and a total annual production of about 7.6 million tons of meat (Eurostat 2017b). In quantitative terms, the cattle production to the EU is $8.1 \%$ of total agricultural production and $18.8 \%$ of livestock 
(Marquer, Rabade, and Forti 2015). Within the EU member states, France, Germany, the United Kingdom and Italy account for more than half of EU beef production (55.9\%) (Eurostat 2017a).

Meat is one of the foods that generates more pressure on the environment within the food sector (Garnett 2011). Faced with an increase in meat consumption in the world of around $50 \%$ in the last 40 years, meat production and agricultural systems in general play a relevant role in the environmental sustainability of the agri-food sector (Alexandratos and Bruinsma 2012). Thus, studies that focus on the determination of environmental impacts in the livestock sector are essential for the development of more sustainable practices (O'Brien et al. 2016).

Life cycle assessment (LCA) is a structured tool with the objective of analyzing the potential environmental impacts throughout the life cycle of a product or service, that is through the stages of production and product use, to the management of waste produced. It also allows guide the environmentally conscious product design, based on the interpretation of the life cycle.

In accordance to ISO (2006a), the LCA of a product, process or service is one of the tools for assessing inputs, outputs and their respective potential environmental impacts throughout their life cycle (Cradle to Gate Approach) considering the raw materials used, the processes of production, transportation, use, end-of-life treatment, recycling and, lastly, final disposal. Consumption of mass and energy resources (inputs) and emissions of substances (output) are the main causes of environmental impacts (Santagata, Ripa, and Ulgiati 2017), Moreover, LCA results are expressed as indicators for several environmental categories, i.e., the results are translated into global warming potential, acidification potential, eutrophication potential, land use and occupation, resource depletion, among others (Pennington et al. 2004).

The aim of this paper is to provide a specific review of the environmental sustainability of beef production in a life cycle assessment context. The importance of using this assessment tool to align sustainable development and food production is also discussed.

\section{Stages of the Life Cycle of Beef Production}

In the basic structure of the industry involving beef production, three phases of its production chain can be distinguished: (i) animal production; (ii) slaughtering and processing of meat; and (iii) the commercialization.

Animal production in beef value chain is important because of the interaction between the breeders and their production stages (rearing and fattening). This stage refers to the main products and services that producers need to raise cattle, including food, veterinary services and animals (genetics) (Lowe et al. 2009). Breeders can be grouped into individual producers, producer groups and cooperatives.

When the animal reaches the ideal weight and age it is slaughtered and undergoes specific processing, some of which may be used for the production of processed meat products. Many of these operations also involve additional processes related to the manufacture of more elaborate meat products, for example, meats for frozen meals.

Finally, marketing is done through wholesalers or direct sales to retailers, where supermarkets, restaurants and food service operators sell the food to the final consumer. The market is included throughout the beef value chain, interacting between the various stages and influencing imports and exports. 


\section{Life Cycle Assessment (LCA)}

\subsection{Stages of Life Cycle Assessment}

LCA shows in detail the inputs and outputs taking into account the coevolution of economic, environmental and social systems due to its process-based approach. Thus, the LCA has important characteristics for decision making, allowing farmers and producers to commercialize their products in a socially and environmentally friendly way to consumers (Land \& Water Australia 2009).

LCA can be divided into four main steps: (1) goal and scope definition, (2) inventory analysis, (3) impact assessment and (4) interpretation of results (Figure 1). ISO (2006a) and ISO (2006b) documents describe and standardize the methodologies related to LCA and environmental management.

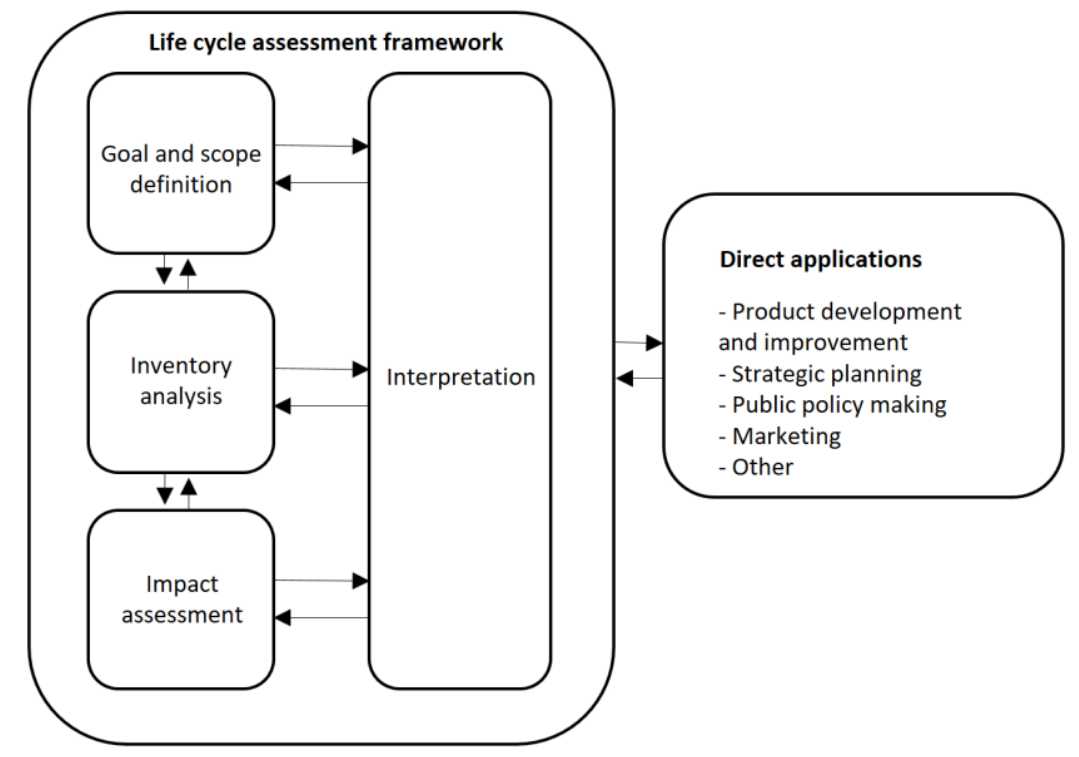

Figure 1: Overview of stages of a life cycle assessment (ISO 2006a)

\subsection{Goal and scope definition}

The initial phase of the LCA is to determine the goal and scope of the study to be carried out. This is an important phase, where the user will determine the limits and context of the system. The level of detail and the target audience is also required at this stage.

In addition to defining the boundary of the study, the type of target audience for whom the results are presented, this stage also determines the main categories of environmental impact.

In summary, at this stage of LCA the following procedures should be defined: (i) objective of the study related to a product or service; (ii) target audience to whom the study is directed; (iii) system boundary and limitations in data collection; (iv) functional unit and allocation procedure; ( $v$ ) environmental impact assessment and impact category.

The functional unit provides a reference to relate the data entering and leaving the system. This unit may vary according to the need of the study. It should take into account a global functional unit, for comparing the results of an evaluation with those of other studies (ISO 2006b).

After identifying all the components of a study, each of them can be seen as an individual system, where it will receive inputs (e.g. energy and raw materials), generate outputs (e.g. waste, emissions and water discharges) and a final product required by the system. In addition to the system impacts as a whole, it should take into account the 
environmental discharges associated with the production, use, transport and final disposal of products.

Process systems are mainly based on the sum of the inputs and outputs of all the components involved, exemplified by inputs of energy and raw materials and outputs of waste and emissions. The system model becomes correct if it does not violate the laws of thermodynamics and mass conservation in which the quantities of output resources will be the same quantities counted at the input of the system.

Table 1 shows the main functional units, the boundaries of the systems, the associated impacts and the respective locations for the LCA of beef production.

This table showed that most of the studies on LCA of beef production take into account the category of impact of global warming potential, also described as climate change. This can be explained due to the focus that recent studies have given to global warming and concern about rising temperatures on Earth. In addition, it was possible to observe a good distribution of LCA studies in beef production in different countries. Thus, different systems can be compared and more input and output information can be collected.

\subsection{Life cycle inventory analysis ( $L C I)$}

Life cycle inventory (LCI) analysis is the second step in LCA. In this phase the values of inputs and outputs within and through the system boundary are identified and quantified. According to the European Commission, Joint Research Centre - Institute for Environment and Sustainability (2010), this procedure includes the use of basic life-cycle data (e.g. data on the production of electricity, purchased materials, or downstream processes such as recycling). Validation of these data is indispensable at this stage. After analyzing the data, the results are used in the Life Cycle Impact Assessment (LCIA).

Data collection is difficult to execute for reasons ranging from the lack of known data, passing by the need of estimating them to the quality of the available data (Willers and Rodrigues 2014). Often some companies may omit or change some important data because of secrecy or even fear of actions related to legal compliance. Therefore, care should be taken in the collection and analysis of data at this stage of LCA.

The collection of data for inclusion in the inventory should follow the guidelines of the purpose and scope of the study. In addition, the data used must be strictly delimited within the boundary of the system. The data that are collected, both by in situ analysis and by questionnaires are called primary data. 


\begin{tabular}{|c|c|c|c|c|}
\hline Location & Functional unit & System boundaries & Impact categories & Reference \\
\hline USA & kg edible beef & cradle-to-gate approach & $\begin{array}{l}\text { Water emissions, cumulative energy demand, land } \\
\text { use, acidification potential, photochemical ozone } \\
\text { creation potential, global warming potential, ozone } \\
\text { depletion potential, abiotic depletion potential, } \\
\text { consumptive water use, and solid waste. }\end{array}$ & $\begin{array}{l}\text { Asem-Hiablie et al. } \\
\qquad \text { (2019) }\end{array}$ \\
\hline Portugal & $\mathrm{kg}$ of beef carcass & cradle-to-gate approach & $\begin{array}{c}\text { Global warming potential, acidification potential, } \\
\text { eutrophication potential, photochemical ozone } \\
\text { creation potential }\end{array}$ & Presumido et al. (2018) \\
\hline Italy & $\mathrm{kg}$ of cooked beef & farm to fork gate & Global warming potential & Vitali et al. (2018) \\
\hline Italy & $\mathrm{kg}$ of live weight & cradle-to-gate approach & $\begin{array}{l}\text { Land occupation, global warming, water depletion, } \\
\text { acidification, eutrophication }\end{array}$ & Bragaglio et al. (2018) \\
\hline Japan & $\begin{array}{l}\text { kg of cold carcass weight of } \\
\text { beef steers }\end{array}$ & cradle-to-gate approach & $\begin{array}{c}\text { Global warming, acidification, and eutrophication, } \\
\text { energy consumption }\end{array}$ & Tsutsumi et al. (2018) \\
\hline Brazil & $\mathrm{kg}$ of live weight & cradle-to-gate approach & $\begin{array}{l}\text { Global warming potential, fossil energy use, land } \\
\text { occupation }\end{array}$ & Kamali et al. (2016) \\
\hline Mexico & $\begin{array}{l}\mathrm{kg} \text { of boneless and fatless } \\
\text { beef }\end{array}$ & cradle-to-gate approach & $\begin{array}{c}\text { Climate change, human toxicity, terrestrial } \\
\text { acidification, freshwater eutrophication, marine } \\
\text { eutrophication, terrestrial ecotoxicity, agricultural } \\
\text { land occupation, water depletion, fossil depletion, } \\
\text { photochemical oxidant formation, freshwater } \\
\text { ecotoxicity, marine ecotoxicity }\end{array}$ & $\begin{array}{l}\text { Huerta, Güereca, and } \\
\text { Lozano (2016) }\end{array}$ \\
\hline Brazil & $\mathrm{kg}$ of beef carcass & cradle-to-gate approach & Global warming potential, land occupation & Cardoso et al. (2016) \\
\hline Thailand & kg of live weight & cradle-to-gate approach & $\begin{array}{c}\text { Climate change, energy consumption, acidification, } \\
\text { eutrophication }\end{array}$ & Ogino et al. (2016) \\
\hline EU & $\mathrm{kg}$ beef meat & cradle to farm gate & $\begin{array}{c}\text { Global warming, acidification, eutrophication, land } \\
\text { use, non-renewable energy use }\end{array}$ & $\begin{array}{c}\text { Nguyen, Hermansen, and } \\
\text { Mogensen (2010) }\end{array}$ \\
\hline
\end{tabular}




\subsection{Life cycle impact assessment (LCIA)}

The Life Cycle Impact Assessment ( $\mathrm{LClA}$ ) includes the results obtained in the $\mathrm{LCl}$ phase to select the impact category and calculate the potential environmental impacts. The categories of environmental impact most studied in beef production are shown in Table 2.

\begin{tabular}{|c|c|c|c|}
\hline Category of Impact & Unity & Substances & Conversion factors \\
\hline & & $\mathrm{SO}_{2}$ & 1.00 \\
\hline \multirow[t]{3}{*}{ Acidification } & $\mathrm{kg} \mathrm{SO}_{2}$-eq & $\mathrm{NH}_{3}$ & 1.88 \\
\hline & & $\mathrm{NO}_{x}$ & 0.70 \\
\hline & & $\mathrm{CO}_{2}$ & 1.00 \\
\hline \multirow[t]{5}{*}{ Global warming } & $\mathrm{kg} \mathrm{CO}_{2}$-eq & $\mathrm{CH}_{4}$ & 28.00 \\
\hline & & $\mathrm{N}_{2} \mathrm{O}$ & 310.00 \\
\hline & & $\mathrm{NO}_{x}$ & 1.35 \\
\hline & & $\mathrm{P}_{2} \mathrm{O}_{5}$ & 14.09 \\
\hline & & $\mathrm{NH}_{3}$ & 3.64 \\
\hline \multirow[t]{4}{*}{ Eutrophication } & kg NO-3-eq & $\mathrm{NO}_{3}$ & 1.00 \\
\hline & & $\mathrm{PO}^{3-}{ }_{4}$ & 10.45 \\
\hline & & $\mathrm{NH}^{+}{ }_{4}$ & 3.60 \\
\hline & & CQO & 0.22 \\
\hline Land use & $\mathrm{m}^{2}$ & - & 1.00 \\
\hline
\end{tabular}

Table 2: Impact categories with related units, contributing substances and characterization factors for the CML 2001 model (Mogensen et al. 2012)

Impact assessment methods are used to facilitate the translation of inventory data into environmentally relevant results. These methods use previously defined factors that contain environmental information about the many substances and resources. The methods are characterized by their measurement principles, characterization, standardization and specific weighting factors.

Each impact category is expressed in the form of a numerical indicator, since this indicator seeks to represent the total environmental load or the significance that the use of a given resource impacts a given environment. For the conversion of the inventory data, it is preferred to use equivalence factors based on scientific knowledge and applicable to all conditions. Thus, the number obtained is a value of the category of environmental impact that becomes an environmental index through the characterization factor.

The CML 2001 model (Guinée et al. 2001) is one of the most used methods for converting the values obtained into environmentally applied results. To avoid uncertainties, this method restricts the model in the initial stages of the cause-effect chain.

Acidification is caused by the release of acid gases or influence on the degree of acidification, mainly from the burning of fossil fuels. For the production of bovine animals, the main element contributing to acidification is ammonia $\left(\mathrm{NH}_{3}\right)$, emitted from the handling of waste (Mogensen et al. 2012).

Global warming has been a widely studied environmental impact category in recent years. The main cause of this impact is the release of greenhouse gases by burning fossil materials. The most important contributors to global warming are nitrous oxide $\left(\mathrm{N}_{2} \mathrm{O}\right)$, methane $\left(\mathrm{CH}_{4}\right)$ and carbon dioxide $\left(\mathrm{CO}_{2}\right)$ (Wei et al. 2016).

A large number of sources related to nitrogen $(N)$ and phosphorus $(P)$ emissions in farms and waste treatment processes causes eutrophication. In areas with high bovine density, these problems are evident due to nutrient leaching (ten Hoeve et al. 2016).

In relation to land use, the production of food and feed for animals occupies a land that could have been used for other purposes, for example, maintaining biodiversity. The quality of the ecosystem is related to biodiversity in the agricultural landscape. It can be mentioned that the 
production of soybeans for pig feed contributes approximately half of the total land consumption for the production of pig meat. Thus, soy production causes the reduction of local biodiversity (Bosire et al. 2016).

The LCIA phase has to be carefully planned to achieve the objective and the initial scope of the LCA. This phase should be coordinated with other stages of the LCA to minimize the possibilities of omissions and uncertainties of the data.

\subsection{Interpretation of $L C A$ results (ILCR)}

Finally, in the interpretation phase, the results are grouped and discussed. The most important points of this phase are the conclusions and recommendations relevant for supporting decision-making, always in agreement with the definition of the objective and scope of the work.

The ILCR phase begins by identifying the key issues, for example, the key processes and resources/emissions that quantitatively contribute most to the magnitude of the impacts. The interpretation includes comprehensiveness, sensitivity and consistency of the checks and also addresses the uncertainty and precision of the results (European Commission, Joint Research Centre - Institute for Environment and Sustainability 2010).

The ILCR occurs in all phases of a LCA. This is because, in comparing two alternatives for the same product, if an alternative shows a greater consumption of material and resources, a purely $\mathrm{LCl}$-based interpretation can be conclusive. However, a study may also aim at comparing all impact categories, especially when there are links between product alternatives, or whether it is desirable to prioritize areas of concern within a LCA. For example, $\mathrm{CO}_{2}$ emissions throughout the life cycle can result in a higher indicator of climate change than in another, but the alternative to minimize this impact involves more pesticides and has a greater potential contribution to toxicological effects (Rebitzer et al. 2004).

\subsection{Advantages and limitations}

In the food area, LCA has been used as an environmental management tool in several industries, such as milk production (Salvador et al. 2016; Pirlo and Lolli 2019), pork production (Wiedemann, McGahan, and Murphy 2018; McAuliffe et al. 2017), beef production (Presumido et al. 2018; Asem-Hiablie et al. 2019) and other agricultural products (Borsato et al. 2019; Guarino et al. 2019).

Despite the great advantages of using the LCA, it has some limiting points. An example of those limitations is that the user often needs to simplify some of the data collected make possible the successful application of the LCA. Unfortunately, this can significantly affect the final results (Turconi, Boldrin, and Astrup 2013). In general, two approaches are used: process chain analysis and input-output analysis. The first uses engineering data and information collected directly in the actuating systems. This procedure requires more time, but generally leads to more accurate results (Finnveden et al. 2009). On the other hand, the input-output analysis system considers monetary data, taking into account the aggregate flows between the sectors (Turconi, Boldrin, and Astrup 2013). Compared with the process chain analysis, the inputoutput analysis produces less dependent and more complete results, but it can present less accurate results than those found in the installations (Joshi 1999).

It must be taken into account that any simplification of the collected data can lead to an erroneous result and minimization of the environmental impacts found. In an attempt to minimize errors, databases are being created to increase and improve the quality of information available to society. 
According to Andersson, Ohlsson, and Olsson (1998), LCA presents several challenges for the food sector. The main difficulty found for this sector is the lack of information on the different processes involved. The LCA in this sector requires a thorough analysis with regard to acquisition of raw materials, transportation, industrial processing, storage, distribution and treatment of the waste produced. Multidisciplinary knowledge is essential for analyzing all the parameters involved.

The challenges are still great for the implementation of LCA, but this methodology can be an analysis used for the environmental impact assessment of the whole human production and consumption systems, contributing to encourage changes in behaviors, attitudes to minimize or eliminate most of danger arising from those environmental impacts.

\section{Environmental Sustainability in Beef Production}

A number of trends in the food industry have become environmental issues and improving process efficiency a constant concern in the value chain management structure of this industry. First, there was a need to invest more in the food sector, due to the increase in population and consequently the increased need for processed foods. On the other hand, there are increasingly demanding customers seeking better quality and more environmentally sustainable food (Fritzson and Berntsson 2006).

The sustainability of meat production systems has been highlighted by the impact of bovine production on the environment and the conservation of resources. Sustainable production involves the conservation of natural resources and the development of new technologies in order to achieve the continuous satisfaction of the human needs of present and future generations. In other words, sustainable meat production is defined as an "ecologically correct and economically viable form of production" (Appleby 2008). Sustainability in meat production involves aspects such as animal health, environmental protection, increased production and concern with food quality.

The main inputs and outputs of a beef production system that influence the environmental performance of this sector are shown in Figure 2.

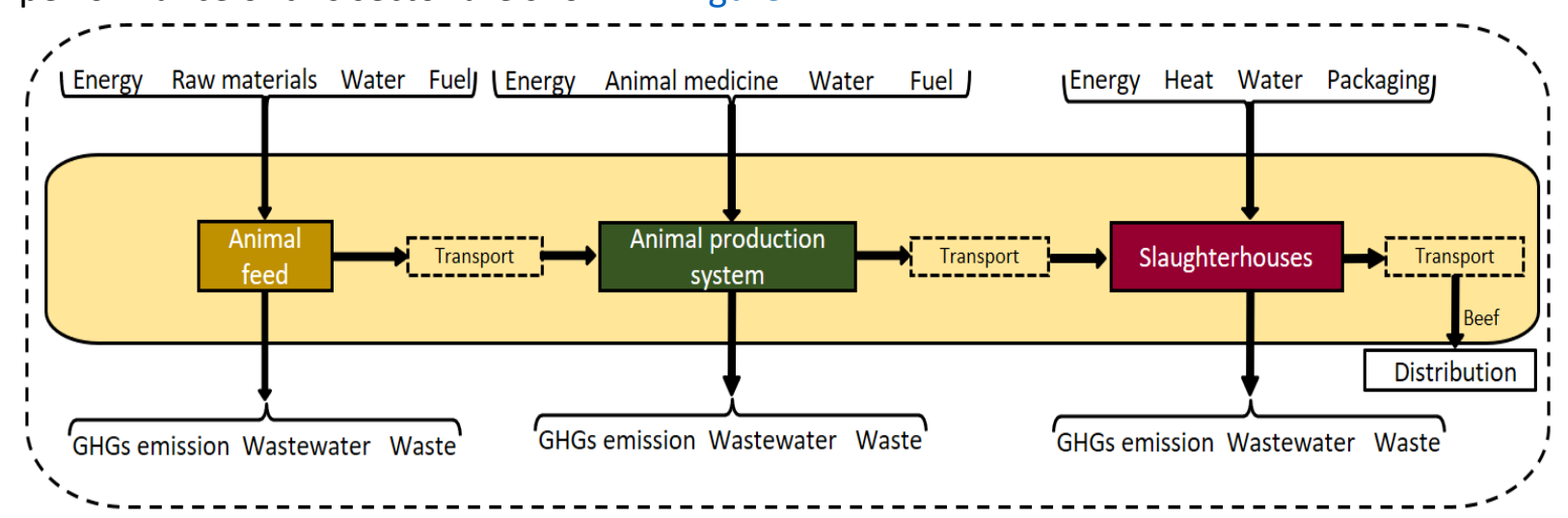

Figure 2: Main inputs and outputs of a beef production system, including animal

feed, animal production and slaughterhouse

Table 3 shows some studies on environmental impact caused by beef production. All studies evaluated environmental sustainability based on the LCA methodology. The categories of impacts most used to evaluate the production of beef are global warming potential, acidification potential, eutrophication potential, land use and water depletion. The high variability in some of the impact categories may be associated with the specific production characteristics of each country, as well as the uncertainties associated with the inputs and/or outputs of each system. 


\begin{tabular}{|c|c|c|c|}
\hline Impact category & Quantity & Unit & Reference \\
\hline \multirow{8}{*}{ Global warming potential } & 22.2 & \multirow{8}{*}{$\mathrm{kg} \mathrm{CO}_{2}$-eq kg ${ }^{-1}$} & Leip et al. (2010) \\
\hline & 17.5 & & Peters et al. (2010) \\
\hline & 23.0 & & Lupo et al. (2013) \\
\hline & 23.4 & & Ruviaro et al. (2015) \\
\hline & 25.4 & & Mogensen et al. (2015) \\
\hline & 23.1 & & iviogensen el al. (2U1כ) \\
\hline & 14.0 & & Ogino et al. (2016) \\
\hline & 22.3 & & Presumido et al. (2018) \\
\hline \multirow{4}{*}{ Acidification potential } & $101-210$ & \multirow{4}{*}{$\mathrm{g} \mathrm{SO}_{2}$-eq kg ${ }^{-1}$} & Nguyen, Hermansen, and Mogensen (2010) \\
\hline & 170 & & Nguyen et al. (2012) \\
\hline & 165 & & Lupo et al. (2013) \\
\hline & 168 & & Presumido et al. (2018) \\
\hline \multirow{5}{*}{ Eutrophication potential } & $116-146$ & \multirow{5}{*}{$\mathrm{g} \mathrm{PO}_{4}^{-3}$-eq kg ${ }^{-1}$} & Cederberg and Darelius (2000) \\
\hline & 87-159 & & Nguyen, Hermansen, and Mogensen (2010) \\
\hline & $104-142$ & & Pelletier, Pirog, and Rasmussen (2010) \\
\hline & 35.1-40.9 & & Lupo et al. (2013) \\
\hline & $123-154$ & & Presumido et al. (2018) \\
\hline \multirow{4}{*}{ Land use } & $111.9-274$ & \multirow{3}{*}{$\mathrm{m}^{2}$ year $^{-1}$} & Huerta, Güereca, and Lozano (2016) \\
\hline & 18.7-27.1 & & Berton et al. (2017) \\
\hline & 32.6-194.4 & & Bragaglio et al. (2018) \\
\hline & 47.4 & $\mathrm{~m}^{2}$ a eq $\mathrm{CB}^{-1}$ & Asem-Hiablie et al. (2019) \\
\hline \multirow{4}{*}{ Water depletion } & 2.47 & \multirow{4}{*}{$\mathrm{m}^{3}$} & Rotz et al. (2015) \\
\hline & $0.084-0.111$ & & Tichenor et al. (2017) \\
\hline & 1.97-3.54 & & Bragaglio et al. (2018) \\
\hline & 2.56 & & Asem-Hiablie et al. (2019) \\
\hline
\end{tabular}

Table 3: Impact categories used to evaluate the environmental sustainability of beef production and its main studies

Beef production is known to be a more environmentally damaging activity compared to pork and poultry production (Eshel et al. 2014). According to some studies, livestock farming accounts for approximately $18 \%$ of global greenhouse gas (GHG) (de Vries and de Boer 2010; González-García et al. 2015). The major contributors are carbon dioxide, which is largely the result of burning fossil fuels; nitrous oxide emitted by manure, urine and through the application of nitrogen fertilizers; and methane that is generated from the digestion of ruminants and waste manure.

In this sense, studies on LCA in the beef production showed that the methane generated from the intestinal tract of the animals can contribute around 60\% for the GHG (Presumido et al. 2018). In an attempt to minimize the percentages of emission, some techniques have been used to intensify the production of pastures and reduce the fattening time of animals until slaughter (White et al. 2014) and consequently reduce GHG emissions.

In addition, beef production involves a wide range of by-products, which if mismanaged can be injurious to the environment. In view of this, these by-products can be used for a variety of purposes, for example for animal feed, and for the production of heat and electricity through biogas. The main purpose of using by-products is to reduce the use of resources in order to avoid the costs of treating this material and add value to the waste. For example, residual animal fat or beef tallow are considered to be a promising alternative raw material for the production of biodiesel.

Another important impact that comes from meat production is the consumption of water. The meat processing industry uses $24 \%$ of the total fresh water consumed and up to $29 \%$ of the consumption of the agricultural sector worldwide (Bustillo-Lecompte and Mehrvar 2015). And as a consequence of the great consumption of water, the wastewater from the beef 
production system also appears as a relevant environmental problem. The meat industry produces large volumes of waste due to animal production and slaughterhouses. According to Huerta, Güereca, and Lozano (2016), residual water from cattle manure is the largest contributor to the categories of environmental impacts related to freshwater eutrophication (99.5\% - 99.6\%), marine eutrophication (65.4\% - 81.6\%) and terrestrial acidification $(98.7 \%$ 98.9\%). In addition, according to the study published by the European Commission (2005), the average water consumption is around $1.62-9.00 \mathrm{~m}^{3}$ per ton of cattle carcass.

It also highlights the use of energy for meat processing, depending on its rational use, energy can also be an impacting factor of meat production. The main energy consumption of meat processing facilities is heating water for cleaning, steam production, operation of electrical equipment and refrigeration. In the production of beef, the energy consumed (electric and fuel) is between 90 and $1094 \mathrm{kWh}$ per ton of cattle carcass (European Commission 2005).

LCA of beef production allows to investigate data inventories and environmental impact assessment and consequently permit to identify which of the beef production system stages are potentially the most impactful to the environment. Moreover, it is possible to identify the main differences between the various production systems and slaughterhouses that can lead to larger amounts of pollution. After identification of the impacts and their location, some improvement opportunities can be proposed to improve production efficiency and reduce the level of pollution released into the environment.

\section{Conclusions}

Meat production is impacting the environment in many ways, resulting in significant impacts on many environmental systems such as air, soil, water, biodiversity and climate change. Beef production is part of a large food industry, which is common in many countries where meat is an important part of the diet of their populations. All emissions require significant treatments for safe and environmentally sustainable disposal. Moreover, increasing the efficiency of animal production is an important route to reduce environmental impacts as well as production costs.

There are several positive points for the use of LCA as a tool for analyzing the environmental performance of the most diverse human activities, such as beef production. LCA has been widely used to assess the environmental performance of meat production, identifying the main environmental impacts associated to the sector.

In addition, this review showed the main functional units, system boundaries and categories of impacts most used to evaluate environmental sustainability in beef production.

\section{References}

Alexandratos, N., and J. Bruinsma. 2012. World agriculture towards 2030/2050: the 2012 revision. ESA Working Paper no. 12-03. Rome: Agricultural Development Economics Division, Food and Agriculture Organization of the United Nation. http://www.fao.org/global-perspectives-studies/resources/detail/en/c/411108/.

Andersson, K., T. Ohlsson, and P. Olsson. 1998. "Screening Life Cycle Assessment (LCA) of tomato ketchup: A case study". Journal of Cleaner Production 6, no. 3-4 (september): 27788. https://doi.org/10.1016/S0959-6526(98)00027-4.

Appleby, M. C. 2008. "Alternatives to conventional livestock production methods". In The wellbeing of farm animals: Challenges and solutions, edited by G. J. Benson and B. E. Rollin, 330-50. USA: Blackwell. https://doi.org/10.1002/9780470344859.ch16. 
Asem-Hiablie, S., T. Battagliese, K. R. Stackhouse-Lawson, and C. Alan Rotz. 2019. "A Life Cycle Assessment of the environmental impacts of a beef system in the USA". The International Journal of Life Cycle Assessment 24, no. 3 (march): 441-55. https://doi.org/10.1007/s11367-018-1464-6.

Berton, M., J. Agabriel, L. Gallo, M. Lherm, M. Ramanzin, and E. Sturaro. 2017. "Environmental footprint of the integrated France-Italy beef production system assessed through a multiindicator approach". Agricultural Systems 155, (july): 33-42. https://doi.org/10.1016/j.agsy.2017.04.005.

Borsato, E., E. Giubilato, A. Zabeo, L. Lamastra, P. Criscione, P. Tarolli, F. Marinello, and L. Pizzol. 2019. "Comparison of water-focused Life Cycle Assessment and water footprint assessment: The case of an Italian wine". Science of the Total Environment 666, (may): 1220-31. https://doi.org/10.1016/j.scitotenv.2019.02.331.

Bosire, C. K., M. S. Krol, M. M. Mekonnen, J. O. Ogutu, J. de Leeuw, M. Lannerstad, and A. Y. Hoekstra. 2016. "Meat and milk production scenarios and the associated land footprint in Kenya". Agricultural Systems 145, (june): 64-75.

https://doi.org/10.1016/j.agsy.2016.03.003.

Bragaglio, A., F. Napolitano, C. Pacelli, G. Pirlo, E. Sabia, F. Serrapica, M. Serrapica, and A. Braghieri. 2018. "Environmental impacts of Italian beef production: A comparison between different systems". Journal of Cleaner Production 172, (january): 4033-43. https://doi.org/10.1016/j.jclepro.2017.03.078.

Brown, M. T., and S. Ulgiati. 2002. "Emergy evaluations and environmental loading of electricity production systems". Journal of Cleaner Production 10, no. 4 (august): 321-34. https://doi.org/10.1016/S0959-6526(01)00043-9.

Bustillo-Lecompte, C. F., and M. Mehrvar. 2015. "Slaughterhouse wastewater characteristics, treatment, and management in the meat processing industry: A review on trends and advances". Journal of Environmental Management 161, (september): 287-302. https://doi.org/10.1016/j.jenvman.2015.07.008.

Cardoso, A. S., A. Berndt, A. Leytem, B. J. R. Alves, I. D. N. O. de Carvalho, L. H. de Barros Soares, S. Urquiaga, and R. M. Boddey. 2016. "Impact of the intensification of beef production in Brazil on greenhouse gas emissions and land use". Agricultural Systems 143, (march): 8696. https://doi.org/10.1016/j.agsy.2015.12.007.

Cederberg, C., and K. Darelius. 2000. "Livscykelanalys (LCA) av nötkött". In Naturresursforum, Landstinget Halland, Halmstad, Sweden.

de Vries, M., and I. J. M. de Boer. 2010. "Comparing environmental impacts for livestock products: A review of Life Cycle Assessments". Livestock Science 128, no. 1-3 (march): 1-11. https://doi.org/10.1016/j.livsci.2009.11.007.

Eshel, G., A. Shepon, T. Makov, and R. Milo. 2014. "Land, irrigation water, greenhouse gas, and reactive nitrogen burdens of meat, eggs, and dairy production in the United States". Proceedings of the National Academy of Sciences of the United States of America 111, no. 33 (august): 11996-2001. https://doi.org/10.1073/pnas.1402183111.

European Commission. 2005. Integrated pollution prevention and control: Reference document on best available techniques in the slaughterhouses and animal by-product industries. Bref code: SA. European Commission.

European Commission, Joint Research Centre - Institute for Environment and Sustainability. 2010. International reference Life Cycle Data System (ILCD) handbook: General guide for 
Life Cycle Assessment - Detailed guidance. Luxembourg: Publications Office of the European Union. https://doi.org/10.2788/94987.

Eurostat. 2017a. Agriculture, forestry and fishery statistics: 2016 edition. Luxembourg: Publications Office of the European Union. https://doi.org/10.2785/917017.

Eurostat. 2017b. Key figures on Europe: 2016 edition. Luxembourg: Publications Office of the European Union. https://doi.org/10.2785/81608.

Finnveden, G., M. Z. Hauschild, T. Ekvall, J. Guinée, R. Heijungs, S. Hellweg, A. Koehler, D.

Pennington, and S. Suh. 2009. "Recent developments in Life Cycle Assessment". Journal of Environmental Management 91, no. 1 (october): 1-21.

https://doi.org/10.1016/j.jenvman.2009.06.018.

Fritzson, A., and T. Berntsson. 2006. "Efficient energy use in a slaughter and meat processing plant-opportunities for process integration". Journal of Food Engineering 76, no. 4 (october): 594-604. https://doi.org/10.1016/j.jfoodeng.2005.06.007.

Garnett, T. 2011. "Where are the best opportunities for reducing greenhouse gas emissions in the food system (including the food chain)?". Food Policy 36, SUPPL. 1 (january): S23-S32. https://doi.org/10.1016/j.foodpol.2010.10.010.

González-García, S., S. Belo, A. C. Dias, J. V. Rodrigues, R. R. D. Costa, A. Ferreira, L. P. D. Andrade, and L. Arroja. 2015. "Life cycle assessment of pigmeat production: Portuguese case study and proposal of improvement options". Journal of Cleaner Production 100, (august): 126-39. https://doi.org/10.1016/j.jclepro.2015.03.048.

Guarino, F., G. Falcone, T. Stillitano, A. I. De Luca, G. Gulisano, M. Mistretta, and A. Strano. 2019. "Life Cycle Assessment of olive oil: A case study in southern Italy". Journal of Environmental Management 238, (may): 396-407. https://doi.org/10.1016/j.jenvman.2019.03.006.

Guinée, J. B., M. Gorrée, R. Heijungs, G. Huppes, R. Kleijn, A. De Koning, L. van Oers, et al. 2001. LCA - An operational guide to the ISO-standards - Part 2b: Operational annex. Institute of Environmental Science (CML), Faculty of Science. Leiden University.

Huerta, A. R., L. P. Güereca, and M. D. L. S. R. Lozano. 2016. "Environmental impact of beef production in Mexico through Life Cycle Assessment". Resources, Conservation and Recycling 109, (may): 44-53. https://doi.org/10.1016/j.resconrec.2016.01.020.

ISO (International Organization for Standardization). 2006a. Environmental management - Life Cycle Assessment - Principles and framework. ISO 14040:2006. Switzerland: ISO.

ISO (International Organization for Standardization). 2006b. Environmental management - Life Cycle Assessment - Requirements and guidelines. ISO 14044:2006. Switzerland: ISO.

Joshi, S. 1999. "Product environmental Life-Cycle Assessment using input-output techniques". Journal of Industrial Ecology 3, no. 2-3: 95-120. https://doi.org/10.1162/108819899569449.

Kamali, F. Pashaei, A. van der Linden, M. P. M. Meuwissen, G. C. Malafaia, A. G. J. M. Oude Lansink, and I. J. M. de Boer. 2016. "Environmental and economic performance of beef farming systems with different feeding strategies in southern Brazil". Agricultural Systems 146, (july): 70-79. https://doi.org/10.1016/j.agsy.2016.04.003.

Land \& Water Australia. 2009. Life Cycle Assessments: A useful tool for Australian agriculture. Climate change research strategy for primary industries. Australia: Australian Government: Rural Industries Research and Development Corporation. http://lwa.gov.au/products/pn30325. 
Leip, A., F. Weiss, T. Wassenaar, I. Perez, T. Fellmann, P. Loudjani, F. Tubiello, et al. 2010. Evaluation of the livestock sector's contribution to the EU greenhouse gas emissions (GGELS) - final report. European Commission, Joint Research Centre.

Lowe, M., G. Gereffi, G. Ayee, R. Denniston, K. Fernandez-Stark, J. Kim, and N. Sang. 2009. A value chain analysis of the U.S. beef and dairy industries: Report prepared for Environmental Defense Fund. Duke Center on Globalization, Governance \& Competitiveness. https://gvcc.duke.edu/wp-content/uploads/CGGC_BeefDairyReport_2-16-09.pdf.

Lupo, C. D., D. E. Clay, J. L. Benning, and J. J. Stone. 2013. "Life-Cycle Assessment of the beef cattle production system for the northern great plains, USA". Journal of Environmental Quality 42, no. 5: 1386-94. https://doi.org/10.2134/jeq2013.03.0101.

Marquer, P., T. Rabade, and R. Forti. 2015. Meat production statistics: Statistics Explained. Eurostat. https://ec.europa.eu/eurostat/statistics-explained/pdfscache/28947.pdf.

McAuliffe, G. A., T. Takahashi, L. Mogensen, J. E. Hermansen, C. L. Sage, D. V. Chapman, and M. R. F. Lee. 2017. "Environmental trade-offs of pig production systems under varied operational efficiencies". Journal of Cleaner Production 165, (november): 1163-73. https://doi.org/10.1016/j.jclepro.2017.07.191.

Mogensen, L., J. E. Hermansen, N. Halberg, R. Dalgaard, J. C. Vis, and B. G. Smith. 2012. "Life Cycle Assessment across the food supply chain". In Sustainability in the Food Industry, edited by C. Baldwin, 115-44. https://doi.org/10.1002/9781118467589.ch5.

Mogensen, L., T. Kristensen, N. I. Nielsen, P. Spleth, M. Henriksson, C. Swensson, A. Hessle, and M. Vestergaard. 2015. "Greenhouse gas emissions from beef production systems in Denmark and Sweden". Livestock Science 174, (april): 126-43. https://doi.org/10.1016/j.livsci.2015.01.021.

Nguyen, T. L. T., J. E. Hermansen, and L. Mogensen. 2010. "Environmental consequences of different beef production systems in the EU". Journal of Cleaner Production 18, no. 8 (may): 756-66. https://doi.org/10.1016/j.jclepro.2009.12.023.

Nguyen, T. T. H., H. M. G. van der Werf, M. Eugène, P. Veysset, J. Devun, G. Chesneau, and M. Doreau. 2012. "Effects of type of ration and allocation methods on the environmental impacts of beef-production systems". Livestock Science 145, no. 1 (may): 239-51. https://doi.org/10.1016/j.livsci.2012.02.010.

O'Brien, D., A. Bohan, N. McHugh, and L. Shalloo. 2016. "A Life Cycle Assessment of the effect of intensification on the environmental impacts and resource use of grass-based sheep farming". Agricultural Systems 148, (october): 95-104.

https://doi.org/10.1016/j.agsy.2016.07.004.

Ogino, A., K. Sommart, S. Subepang, M. Mitsumori, K. Hayashi, T. Yamashita, and Y. Tanaka. 2016. "Environmental impacts of extensive and intensive beef production systems in Thailand evaluated by Life Cycle Assessment". Journal of Cleaner Production 112, (january): 22-31. https://doi.org/10.1016/j.jclepro.2015.08.110.

Pelletier, N., R. Pirog, and R. Rasmussen. 2010. "Comparative life cycle environmental impacts of three beef production strategies in the Upper Midwestern United States". Agricultural Systems 103, no. 6 (july): 380-89. https://doi.org/10.1016/j.agsy.2010.03.009.

Pennington, D. W., J. Potting, G. Finnveden, E. Lindeijer, O. Jolliet, T. Rydberg, and G. Rebitzer. 2004. "Life Cycle Assessment Part 2: Current impact assessment practice". Environment International 30, no. 5 (july): 721-39. https://doi.org/10.1016/j.envint.2003.12.009.

Peters, G. M., H. V. Rowley, S. Wiedemann, R. Tucker, M. D. Short, and M. Schulz. 2010. "Red meat production in Australia: Life Cycle Assessment and comparison with overseas 
studies". Environmental Science and Technology 44, no. 4: 1327-32. https://doi.org/10.1021/es901131e.

Pirlo, G., and S. Lolli. 2019. "Environmental impact of milk production from samples of organic and conventional farms in Lombardy (Italy)". Journal of Cleaner Production 211, (february): 962-71. https://doi.org/10.1016/j.jclepro.2018.11.070.

Presumido, P. H., F. Sousa, A. Gonçalves, T. C. Dal Bosco, and M. Feliciano. 2018. "Environmental impacts of the beef production chain in the Northeast of Portugal using Life Cycle Assessment". Agriculture 8, no. 10 (october). https://doi.org/10.3390/agriculture8100165.

Rebitzer, G., T. Ekvall, R. Frischknecht, D. Hunkeler, G. Norris, T. Rydberg, W. P. Schmidt, et al. 2004. "Life Cycle Assessment Part 1: Framework, goal and scope definition, inventory analysis, and applications". Environment International 30, no. 5 (july): 701-20. https://doi.org/10.1016/j.envint.2003.11.005.

Rotz, C. A., S. Asem-Hiablie, J. Dillon, and H. Bonifacio. 2015. "Cradle-to-farm gate environmental footprints of beef cattle production in Kansas, Oklahoma, and Texas". Journal of Animal Science 93, no. 5 (may): 2509-19. https://doi.org/10.2527/jas.2014-8809.

Ruviaro, C. F., C. M. De Léis, V. D. N. Lampert, J. O. J. Barcellos, and H. Dewes. 2015. "Carbon footprint in different beef production systems on a southern Brazilian farm: A case study". Journal of Cleaner Production 96, Article number 3972 (june): 435-43. https://doi.org/10.1016/j.jclepro.2014.01.037.

Salvador, S., M. Corazzin, E. Piasentier, and S. Bovolenta. 2016. "Environmental assessment of small-scale dairy farms with multifunctionality in mountain areas". Journal of Cleaner Production 124, (june): 94-102. https://doi.org/10.1016/j.jclepro.2016.03.001.

Santagata, R., M. Ripa, and S. Ulgiati. 2017. "An environmental assessment of electricity production from slaughterhouse residues. Linking urban, industrial and waste management systems". Applied Energy 186, (january): 175-88.

https://doi.org/10.1016/j.apenergy.2016.07.073.

ten Hoeve, M., B. Gómez-Muñoz, L. S. Jensen, and S. Bruun. 2016. "Environmental impacts of combining pig slurry acidification and separation under different regulatory regimes - A Life Cycle Assessment". Journal of Environmental Management 181, (october): 710-20. https://doi.org/10.1016/j.jenvman.2016.08.028.

Tichenor, N. E., C. J. Peters, G. A. Norris, G. Thoma, and T. S. Griffin. 2017. "Life cycle environmental consequences of grass-fed and dairy beef production systems in the Northeastern United States". Journal of Cleaner Production 142, (january): 1619-28. https://doi.org/10.1016/j.jclepro.2016.11.138.

Tsutsumi, M., Y. Ono, H. Ogasawara, and M. Hojito. 2018. "Life-cycle impact assessment of organic and non-organic grass-fed beef production in Japan". Journal of Cleaner Production 172, (may): 2513-20. https://doi.org/10.1016/j.jclepro.2017.11.159.

Turconi, R., A. Boldrin, and T. Astrup. 2013. "Life Cycle Assessment (LCA) of electricity generation technologies: Overview, comparability and limitations". Renewable and Sustainable Energy Reviews 28: 555-65. https://doi.org/10.1016/j.rser.2013.08.013.

USDA (United States Department of Agriculture). 2016. Livestock and poultry: World markets and trade. Office of Global Analysis. Foreign Agricultural Service, 1-31. United States Department of Agriculture, Foreign Agricultural Service. https://usda.library.cornell.edu/concern/publications/73666448x?locale=en. 
Vitali, A., G. Grossi, G. Martino, U. Bernabucci, A. Nardone, and N. Lacetera. 2018. "Carbon footprint of organic beef meat from farm to fork: A case study of short supply chain". Journal of the Science of Food and Agriculture 98, no. 14 (november): 5518-24. https://doi.org/10.1002/jsfa.9098.

Wei, T., W. Dong, Q. Yan, J. Chou, Z. Yang, and D. Tian. 2016. "Developed and developing world contributions to climate system change based on carbon dioxide, methane and nitrous oxide emissions". Advances in Atmospheric Sciences 33, no. 5 (may): 632-43. https://doi.org/10.1007/s00376-015-5141-4.

White, R. R., M. Brady, J. L. Capper, and K. A. Johnson. 2014. "Optimizing diet and pasture management to improve sustainability of U.S. beef production". Agricultural Systems 130, (september): 1-12. https://doi.org/10.1016/j.agsy.2014.06.004.

Wiedemann, S. G., E. J. McGahan, and C. M. Murphy. 2018. "Environmental impacts and resource use from Australian pork production determined using Life Cycle Assessment. 2. Energy, water and land occupation". Animal Production Science 58, no. 6: 1153-63. https://doi.org/10.1071/AN16196.

Willers, C. D., and L. B. Rodrigues. 2014. "A critical evaluation of Brazilian Life Cycle Assessment studies". International Journal of Life Cycle Assessment 19, no. 1 (january): 144-52. https://doi.org/10.1007/s11367-013-0608-y. 